\title{
PRELIMINARY REPORT ON THE EIGHTEENTH EXCAVATION SEASON OF THE ARCHAEOLOGICAL EXPEDITION TO WAD BEN NAGA
}

\author{
Pavel Onderka - Vlastimil Vrtal - Gabriela Jungová - Jiří Honzl ${ }^{1}$
}

\begin{abstract}
The eighteenth excavation season of the Archaeological Expedition to Wad Ben Naga focused on the continued excavations of the so-called Isis Temple (WBN 300 ; more specifically on the frontal part of the proper temple), the continued excavations of structure WBN 250, and the continued excavations of cemetery WBN C260.
\end{abstract}

KEYWORDS: Meroitic archaeology - Sudanese archaeology - Wad Ben Naga - Isis Temple (WBN 300)

\section{Introduction}

The eighteenth excavation season of the Archaeological Expedition to Wad Ben Naga took place between 21 October and 16 December 2019. Archaeological works were launched on 26 October 2019 and were concluded 10 December 2019. The season was carried out under the guidelines for 'archaeological excavations' as defined by the Ordinance for the Protection of Antiquities of 1999.

Following the conclusion of the archaeological works at Wad Ben Naga, the expedition visited the Sheikhan Museum in al-Obeid, the North Kordofan State, between 11 and 13 December 2019, with the purpose to study objects from the Sudanese excavations at Wad Ben Naga exhibited there.

The mission was headed by Pavel Onderka (director) and Juweriya Osman Mohamed Zain (inspector of the National Corporation for Antiquities and Museums). It further consisted of Vlastimil Vrtal (archaeologist), Jiří Honzl (archaeologist), and Gabriela Jungová (anthropologist).

The works of the eighteenth season focused on [1] the continued excavations of the so-called Isis Temple (WBN 300), namely the frontal part of the proper temple; [2] the continued excavations of structure WBN 250 and [3] the continued excavations of cemetery WBN C260. In connection with the exploration of the socalled Isis Temple, [4] the northernmost tumulus of cemetery WBN C300, located

1 Contacts: Pavel Onderka \& Vlastimil Vrtal \& Jiří Honzl \& Gabriela Jungova, National Museum Naprstek Museum of Asian, African and American Cultures, Ancient Near East and Africa Collection, Prague, Czech Republic; e-mail: pavel.onderka@nm.cz, vlastimil.vrtal@nm.cz, jiri.honzl@nm.cz, gabriela.vrtalova@nm.cz. The article was written within the framework of the project 'The Building Program of King Natakamani and Queen Amanitore' supported by the Czech Science Foundation (grant no. 18-00454S).

The Archaeological Expedition to Wad Ben Naga wishes to express its sincerest thanks and gratitude to the National Corporation for Antiquities and Museums, namely to Dr. Hassan Hussein Idris, Dr. Abdel-Rahman Ali Mohamed, Dr. Hatem el-Nour, Juweriya Osman, and Iglal Malik, and Dr. Nasreldin Shulgami, the Honorary Consul-General of the Slovak Republic in the Republic of the Sudan. 
on top of kom C covering the area of the anticipated Isis Temple (WBN 300) was excavated [Fig. 1].

\section{[1] Continued excavations of the so-called Isis Temple (WBN 300)}

Summary of works of the previous seasons

The complex of the so-called Isis Temple (WBN 300) began to be explored in the course of the sixteenth excavation season (spring 2018), when the remains of the temple's kiosk (WBN 390) were unearthed. The discovery of the kiosk indicated the anticipated location of the main axis of the proper temple - a discovery that helped to shape the planning of works in the subsequent excavation seasons. The axis of the temple is oriented to the rising sun at the winter solstice, as was the case of most Meroitic monumental buildings. In connection with the unearthing of the remains of Kiosk WBN 390, a medium-sized cemetery WBN C260 began to be explored. Ritual deposits, most likely

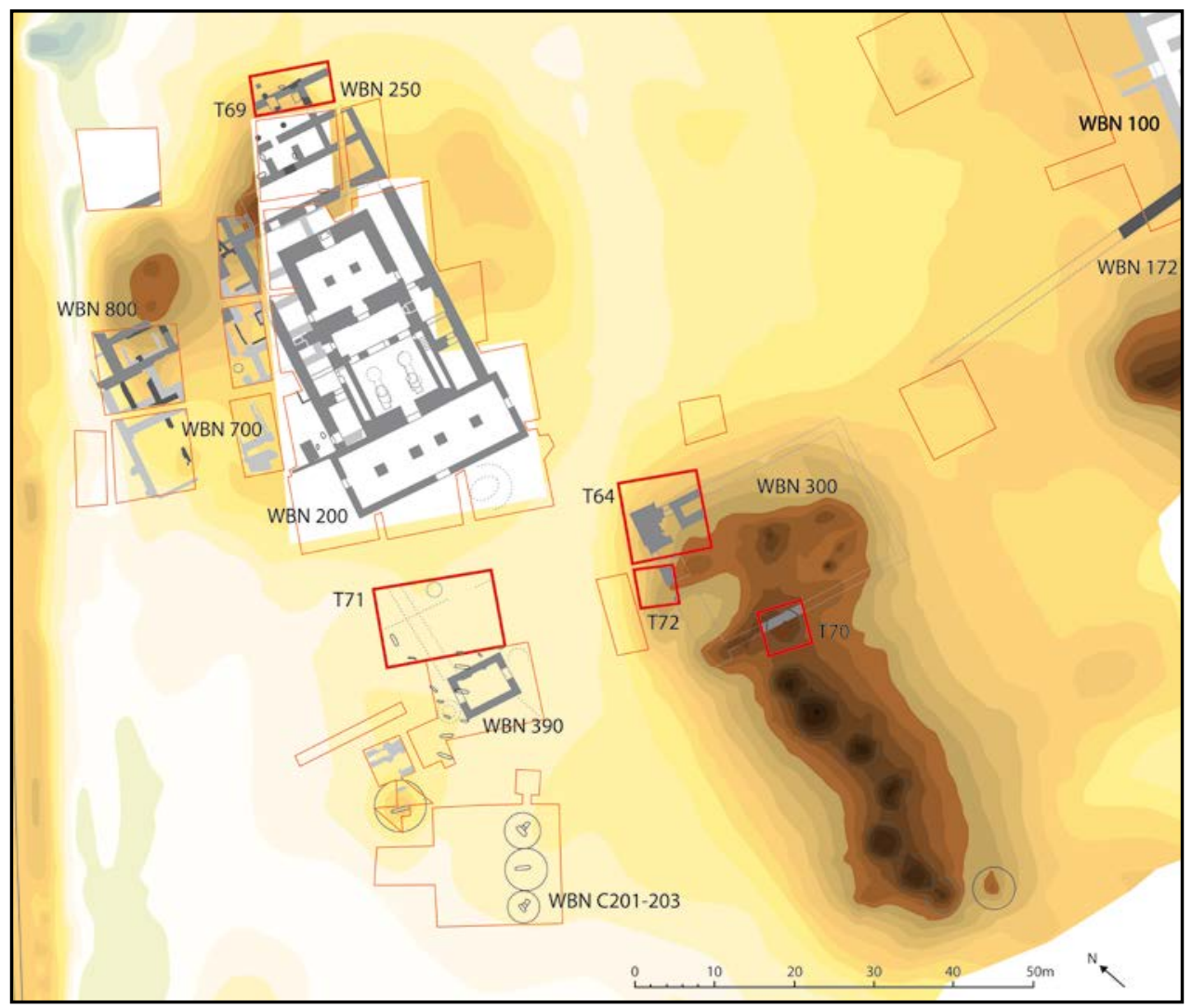

Fig. 1. Western part of Central Wad Ben Naga. Trenches excavated during the eighteenth excavation season are highlighted in bold red.

(Illustration: Pavel Onderka, Vlastimil Vrtal, and Gabriela Jungová). 
connected with the initiations of the building program of King Natakamani and Queen Amanitore, were discovered on the western edge of the kiosk. ${ }^{2}$

During the seventeenth excavation season, two trenches at the northern end of the kom $C$ were explored. Trench T61 $(10 \times 5 \mathrm{~m})$ revealed the space in front of the temple's pylon (the only features unearthed were several postholes), while trench T64 $(10 \times 10 \mathrm{~m})$ revealed a complex archaeological situation dominated by massive brickwork features. ${ }^{3}$ Due to the archaeological complexity and time schedule of the seventeenth season, the excavations within T64 could not be completed and hence continued during the eighteenth season. Another trench, T72, was opened to the south of T64.

\section{Trench $T 64$}

T64 possessed the original dimensions of $10 \times 5 \mathrm{~m}$ [Fig. 2]. During the eighteenth season, it was expanded to a square with the side of $10 \mathrm{~m}$. The trench eventually encompassed the western part of the massive brickwork (which, as it turned out in the course of the current excavations, formed part of the northern exterior wall of the temple, but must have also served its own purpose; the brickwork in all probability formed stairs leading to the roof of the temple; FEA 212), the northern part of the temple's pylon (FEA 227) and a portion of the north-west corner of the temple's hypostyle hall (WBN 301).

Between the brickwork (FEA 212) and the pylon's northern tower (FEA 227) was set a small side door, paved with a sandstone threshold (FEA 220). Similar side doors are attested in many Meroitic temples. The Amun Temple at Naga (N 100), may serve as an example. ${ }^{4}$

A small podium (FEA 241), built of reused fired bricks, was discovered in the corridor leading from the hypostyle hall (WBN 301) to the side door.

In the middle of the pylon's northern tower, a side doorway (FEAs 239-253 - sandstone block casing; FEA 229 - a threshold formed by a single sandstone slab; FEAs 250-251 - two sandstone blocks with door stopper holes connected with a rail (FEA 252) carved into the paving made of fired bricks) was inserted (a similar arrangement may be best documented by the First Pylon of the Isis Temple at Philae). The doorway was cased with stone, while the pylon was built of fired bricks. Large sandstone blocks (FEA 211, S927-S930) forming the jambs of the side entrance had collapsed inside of the hypostyle hall.

To the north of the entrance was a ferriferous sandstone block (FEA $225=$ S966) covered with a lime plaster partly inserted into the mass of the pylon's tower. Remains of five columns of Egyptian hieroglyphic text, which sought inspiration from texts in the flagpole niches (Inschrift am Schlitz für den Flaggenmast) of the First Pylon of the Isis Temple at Philae, ${ }^{5}$ were on the outer face of the block. The text represents a shortened version of the Philae pattern and is introduced as a recitation by Isis [Pl. 1].

The preserved lowermost register of the jamb and casing of the doorway were decorated with the figures representing fecundity gods bringing offerings in the form of

2 Onderka et al. 2019a, pp. 134-136.

3 Onderka et al. 2019b, pp. 108-109.

4 Kroeper 2006, Fig. 6, gateway L and M.

5 Junker 1958, p. 17. 


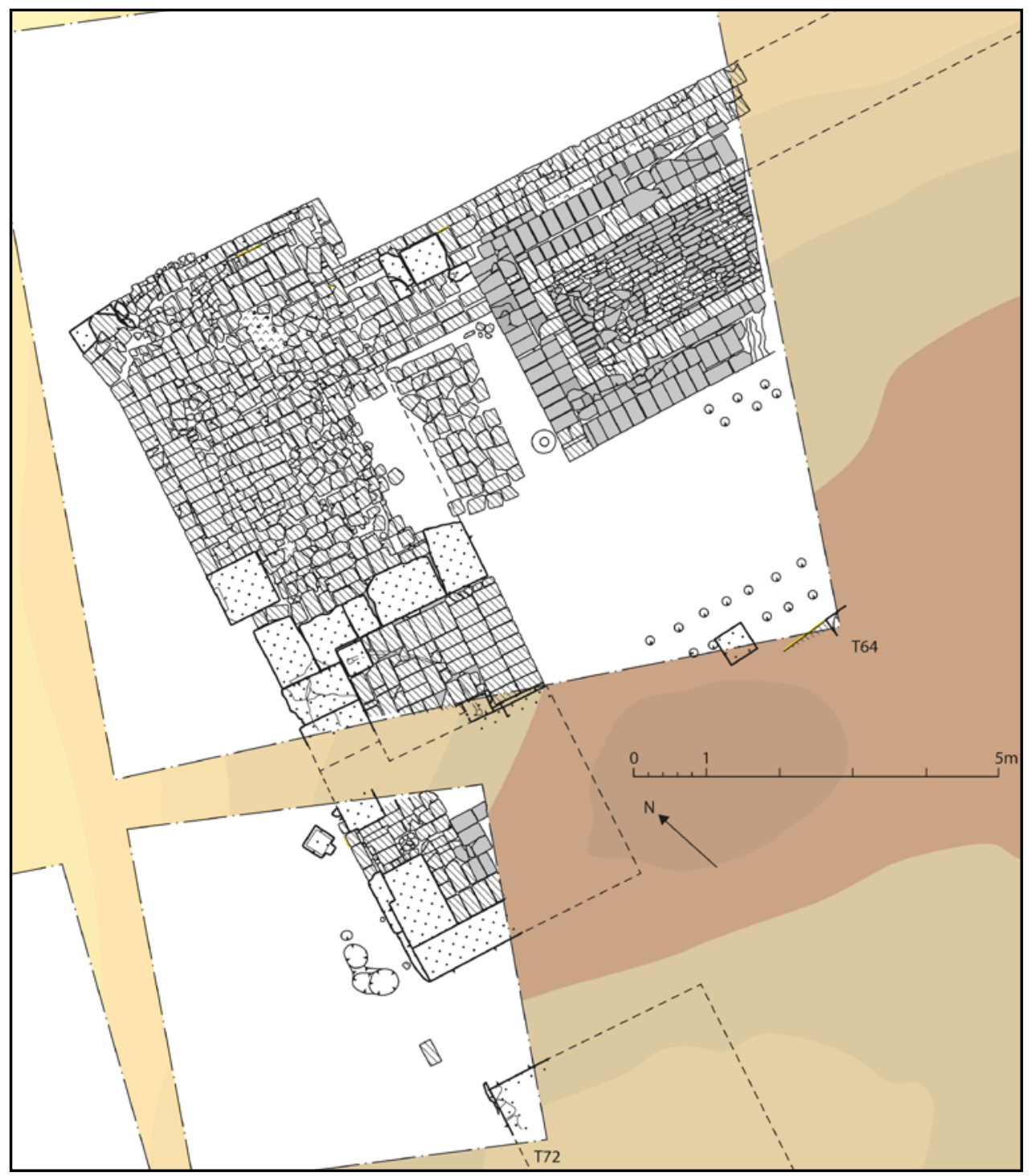

Fig. 2. Top plans of trenches T64 and T72 at the end of excavations (Illustration: Pavel Onderka, Jiří Honzl, and Vlastimil Vrtal).

flower wreaths [Pl. 2]. The doorway was equipped with a one-winged door with door stoppers, rails of which are seen in the floor paved with fired bricks.

The lower part of a column (FEA 233) supporting the roof of the hypostyle hall (WBN 301) was discovered in the trench. ${ }^{6}$ The decorated base of the columns had the dimensions of an almost perfect cube with the size of ca. $85 \times 85 \times 85 \mathrm{~cm}$. Column drums

6 The ongoing excavations suggest that the hypostyle hall (WBN 301) possessed a single pair of columns. 
placed over the column base were found in fragments. They bore both pictorial and textual decoration carried out in low relief, namely divine and royal figures accompanied by captions written in Egyptian hieroglyphic texts (S1001-S1014).

It may not be ruled out, actually it is highly probable that the column recorded in a ground plan sketch by Erbkam during excavation in the temple in March $1844^{7}$ is identical with the column, the base and fragments of which were unearthed in the present trench. This assumption is supported by a relatively recent intrusion into the kom's stratigraphy recorded in the trench. A secondary wall was built against the column and extended westward, i.e. towards the proper pylon.

A small bark stand (FEA 254; $40 \times 40 \mathrm{~cm}, \mathrm{~h} .38 \mathrm{~cm}$ ) was discovered inside of the respective section of the hypostyle hall. Two aligned pair rows of precisely placed holes were identified in the floor of the room. The average diameter of the holes is $15 \mathrm{~cm}$.

The northern tower of the pylon was almost entirely built of fired bricks. Stone, namely sandstone, was used in order to boost the pylon's statics and for special architectural features. The outer corners of the pylon were supported by sandstone blocks (FEAs 246 and 247). Sandstone blocks forming the cavetto cornice (FEA 245) were found collapsed in front of the façade of the pylon. A ferriferous sandstone block with an inscription in Egyptian hieroglyphs was set into the mass of the pylon, divided from the jambs of the northern side entrance by a brick wall segment.

Around the pylon, fragments of modelled and painted fragments of lime plaster were found. In terms of colouring, the usual Meroitic repertoire of red, blue, and yellow was identified. Occasionally, fragments were large enough to enable the interpretation of the decoration. The modelling was used for outlining parts of human body (e.g. a chin with mouth, hands, etc.), while colouring was primarily used for illustrating the garments that divine and royal figures were dressed in.

A fragment of a head of Bes (capturing the god's eye; SM19/056) [Pl. 3] was discovered during excavations in the trench. The fragment might have been relocated with its likely origin being in the Typhonium (WBN 200) or a structure to its north.

\section{Trench $T 72$}

The trench $(5 \times 5 \mathrm{~m})$, located to the south of T65 and east of T61, revealed the main entrance to the temple. The main entrance - similar to the north side entrance - was equipped with stone jambs (FEAs 264 and 265) decorated in the lowermost register with depictions of the fecundity gods pouring water from tall vessels.

One of the upper registers seems to have been decorated with the depiction of the sovereign supporting the sky, a topic known from the two bark stands discovered in the temple by the Lepsius expedition (the so-called Altars A and B), ${ }^{8}$ as suggested by a block bearing a column of a text in Egyptian hieroglyphs describing the captioned activity as, 'supporting the sky like (the god) Shu (does it)' (rmn p.t mj šw). Fragments of blocks bearing the depiction of $p$.t-sign filled with distinctively Meroitic stars have been found as well.

7 Cf. Priese 1984, p. 16, Abb. 3.

8 Onderka et al. 2014, pp. 140-142, cat. nos. 47-48. 
From the preserved blocks, the original appearance of the main entrance's architrave could have been reconstructed. The architrave together with the outer casing of the door jambs had collapsed into the open space in front of the temple. To the left of the main entrance, a stand for an offering table (?) made of sandstone and covered with lime plaster was discovered. The ground plan of the stand imitated the shape of Meroitic offering tables.

Fragmented remains of cranial and postcranial skeleton of an adult individual were uncovered in the south-east part of the trench. The remains were poorly preserved, incomplete, and heavily disturbed.

\section{[2] Continued excavations of structure WBN 250}

\section{Trench T69}

Trench T69 $(10 \times 5 \mathrm{~m})$ was set at the northern limit of so-called $\mathrm{kom} A$, to the north of previously excavated area of trench T4. ${ }^{9}$ In 2011, the excavations in trench T4 revealed a monumental building labelled as WBN 250, with a complex distribution of rooms. Remains of the structure, which abutted the so-called Typhonium (WBN 200) from the north, were later uncovered also in trenches $\mathrm{T} 36^{10}$ and $\mathrm{T} 44^{11}$ [Fig. 3]. The excavations in trench T69 were aimed at uncovering continuation of this building and to cast additional light about its size, plan, and development.

The excavations in the trench uncovered structural features attributable to at least two horizons of constructional activity, each followed by destruction linked to initial conflagration. The remains of a mudbrick wall with fired brick casing on its northern face that transects the trench in the east-west direction (FEAs 527-556-581), mark the presence of the earliest structure [Fig. 4, Pl. 4]. The wall was built directly on levelled sāra bedrock (FEA 565). In its exterior, a sandstone column (FEA 547) was built on a fired brick platform (FEA 567). The column likely belonged to the same phase of constructional activity - the platform also rested directly on the bedrock, the column shared orientation with the exterior wall, and was situated by the main axis of structure WBN 250. The remaining area in the exterior was covered with the same type of mortar floor (FEA 566) as in trenches T36 and T44 (FEA 509), although it was situated 0.3-0.6 m lower. Already at the time of construction, the structure thus had to be built on a mild slope. In the east, the mortar floor was cut by pits - possibly remains of scaffolding (FEAs 557-564). In the interior, a mudbrick wall (FEA 583?; continuation of FEA 118 from trench T4) joined the exterior wall from the south and formed two rooms. The floor of the one to the east was paved with mudbricks (FEA 530) and elevated ca. $0.6 \mathrm{~m}$ above the mortar floor in the exterior. The brick floor finds direct analogy in other rooms of structure WBN 250, excavated in trenches T4 and T36, and situated at the very same level. Judging from the height difference, the mudbrick floors clearly compensated for the uneven terrain. No similar mudbrick floor was found in the room to the west.

The general orientation of the abovementioned walls and the presence of the mudbrick floor, which was most likely bound to them, seem to indicate that it was this constructional horizon in trench T69 that was part of structure WBN 250.

9 See Onderka 2012, pp. 127-132, Pls. 8-9.

10 Two rooms with a mudbrick floor and an exterior wall; see Onderka et al. 2017a, pp. 115-116, Figs. 2-3.

11 A staircase and an exterior wall; see Onderka et al. 2018, pp. 99-100, Fig. 3, Pls. 1, 2 b. 


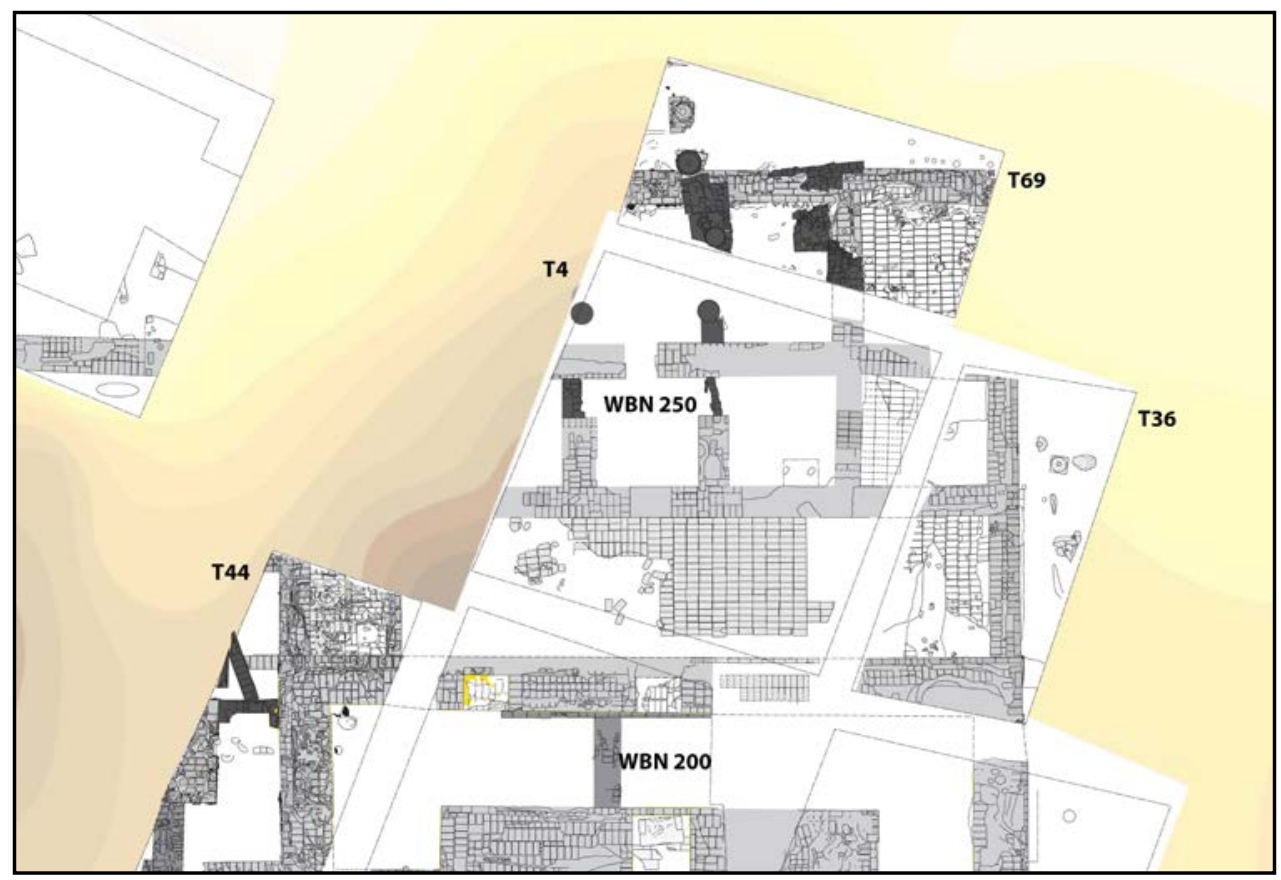

Fig. 3. Top plan of structure WBN 250 and the northern part of the Typhonium (WBN 200) with trench T69 at the end of excavations. (Illustration: Pavel Onderka, Vlastimil Vrtal).

Its construction was estimated to have occurred concurrently or shortly after the erection of the Typhonium in the reign of Natakamani (and Amanitore), i.e. in the mid- $1^{\text {st }}$ century CE. ${ }^{12}$ A few pottery finds retrieved from the mortar floor and fill underneath the mudbrick floor in trench T69 (including e.g. ledge-rimmed bowls) seem to roughly confirm this dating.

Subsequently, the exterior wall was almost razed to the ground - an event followed by formation of mud fill with some debris (or trampled floor deposits) in both the interior and exterior (FEAs 571, 582, 549, and 543). The strata were interspersed with thin horizontal layers of ash covering considerable areas. Activities such as the formation of fireplaces (FEAs 545, 572, and 579) and small pits in the mudbrick floor (FEAs 532-540) may fall to within this period. A small podium (FEA 568) was also built over the remains of wall FEA 583 from fired brick and mudbrick fragments, including plastered cavetto cornice bricks; and a section of a fired brick wall with a different orientation (FEA 580) covered the denuded exterior wall and its debris (FEA 539). Following accumulation of additional mud and debris (FEAs 549 and 552), two sandstone columns of different diameters (FEAs 525 and 531) were erected (or deposited) over the denuded wall and to the south of it, respectively. The latter column was further encircled by an irregular

12 For dating the construction of the Typhonium, see inter alia Onderka 2016, p. 56; Onderka and Vrtal 2018, p. 419; for dating the construction of WBN 250, see Onderka et al. 2017a, p. 115; Onderka et al. 2018, p. 100. 


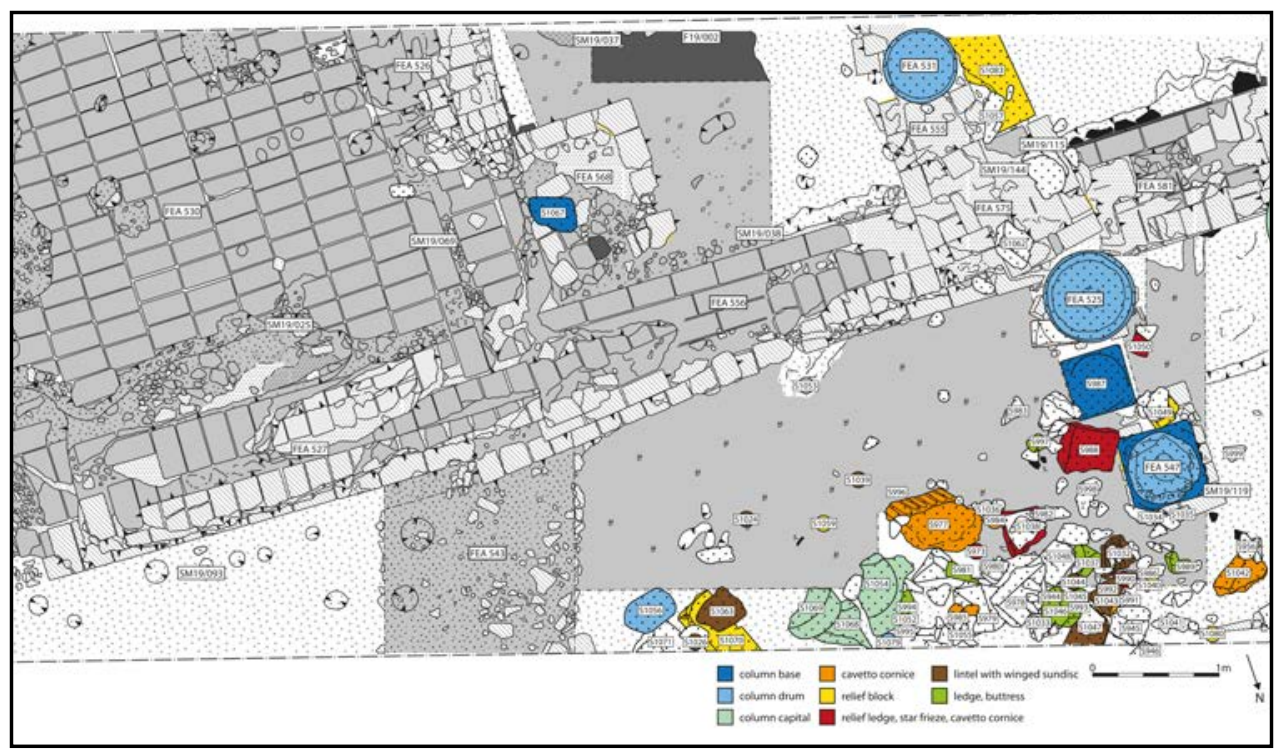

Fig. 4. Detailed top plan of trench T69 at the end of excavations with highlighted position of recovered fragments of sandstone architectural elements

(Illustration: Vlastimil Vrtal).

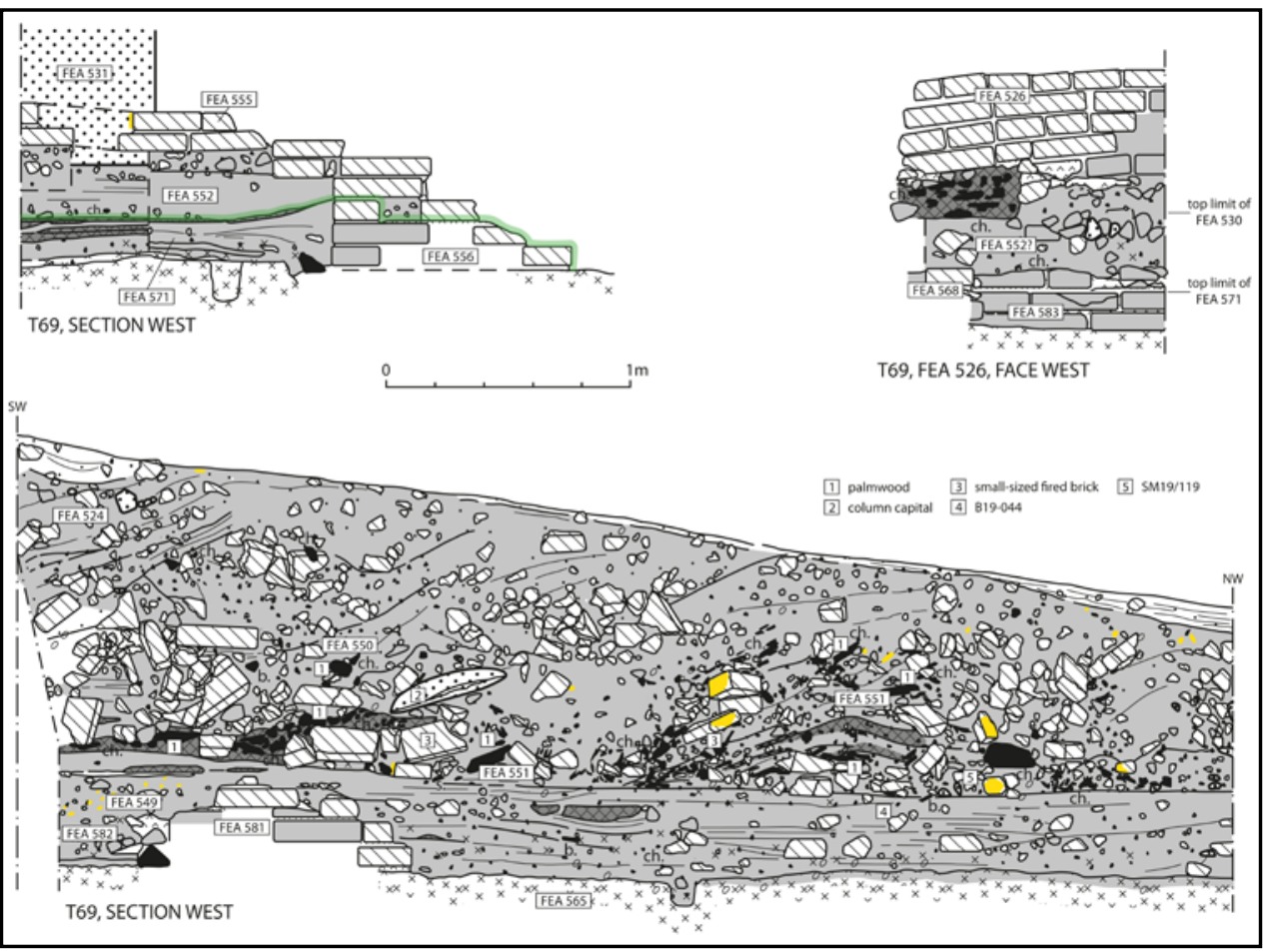

Fig. 5. Selected sections of trench T69 (Illustration: Vlastimil Vrtal). 


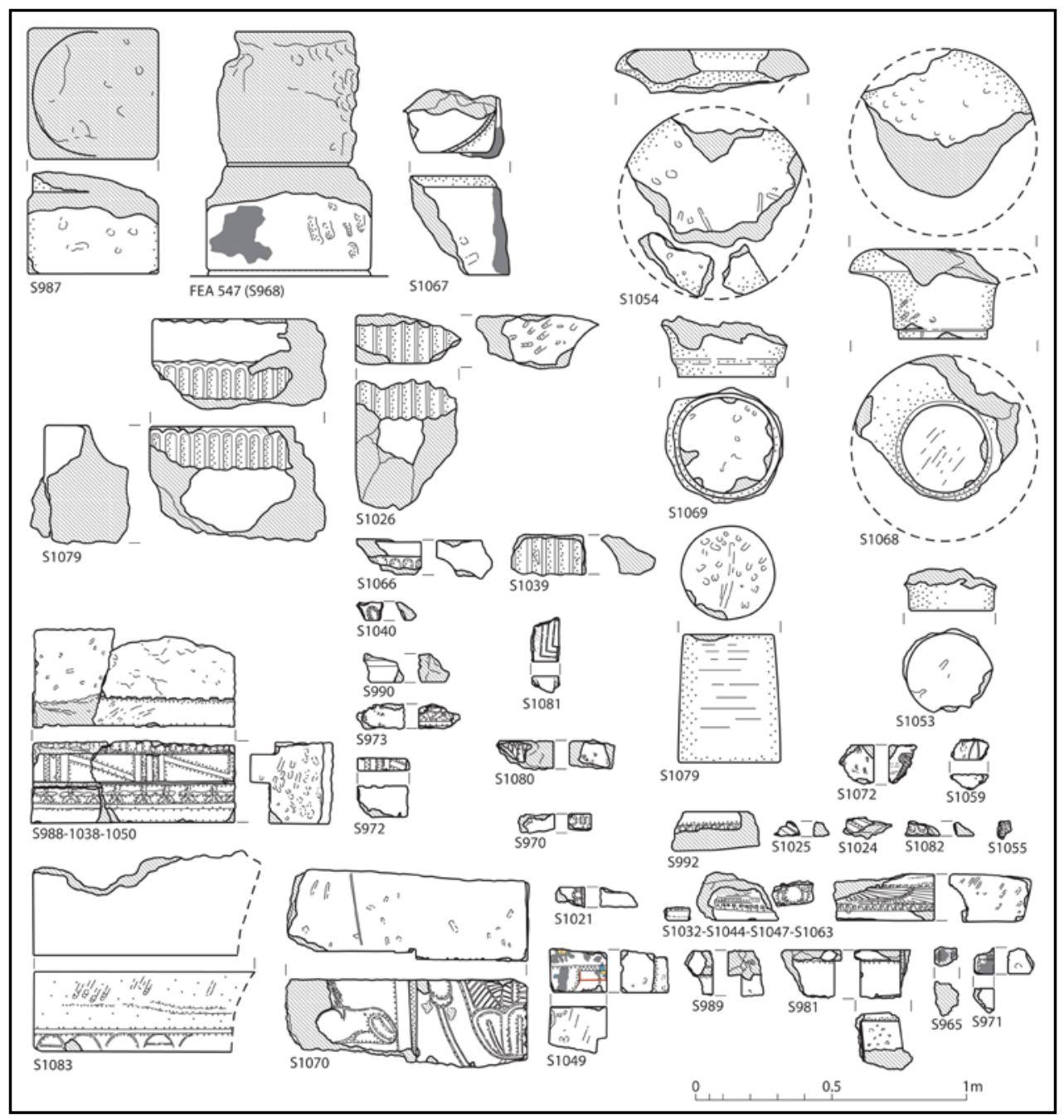

Fig. 6. Selection of fragments of sandstone architectural elements recovered from trench T69 (Illustration: Vlastimil Vrtal).

wall or podium (FEA 555-575), built of reused fired bricks and brick fragments, and a large reused sandstone block with relief decoration (S1083) [Fig. 6]. Such manner of construction finds direct parallel in the neighbouring trench T4, in which a sandstone column (FEA 104) was similarly built on debris and surrounded by a reused (?) brick and a sandstone architrave construction (FEA 125). ${ }^{13}$ Roughly concurrently with the erection of column FEA 531 and podium 555-575, the wall running to the south was likely rebuilt, as its upper part with fired brick casing on the western face (FEA 526) rested on thick layer of debris (FEA 552) overlying mudbrick wall FEA 583 [Fig. 5]. 
Setting these various construction events into a chronological frame seems difficult. It is fairly possible that at least some may have been connected with functional alterations observed in trench T4 and manifested by blocked entrances. ${ }^{14}$ The composition of pottery from the strata preceding these constructions in trench T69 conformed with standard repertoire only broadly datable to the $1^{\text {st }}-3^{\text {rd }}$ century CE.

Following this secondary construction activity, severe destruction of the building's architecture could be noted in the stratigraphic record, marked by several events of debris accumulations (FEAs 523-524, 529, 544, 550-551, 553-554). The initial accumulation(s) were marked by heavy conflagration, as evidenced by burnt remains of palmwood and acacia (?) beams, probably from roofing. From the debris, several cavetto cornice fired bricks were retrieved, as well as fired bricks of a smaller size $(0.29 \times 0.13 \times$ $0.06 \mathrm{~m}$ ), presumably used for roofing. A piece of a faience tile (SM19/119) may also come from the building. Predominantly to the north of the former exterior wall, numerous sandstone architectural elements were found in the debris [Figs. 4, 6], including column bases (S987, S1067) [Fig. 6], column drums (S1079) [Fig. 6], at least two campaniform column capitals (S1053-S1054, S1068-S1069) [Figs. 5-6], fragments of a lintel (?) with winged sun-disc (S992, S1024-1025, S1032, S1044, S1047, S1055, S1063, S1082) [Fig. 6], and blocks with a star frieze under a rectangular ledge with stylized mat binding known from Egyptian torus moulding, surmounted by a cavetto cornice (S972-S973, S988, S990, S1026, S1038-1040, S1050, S1066, S1079) [Fig. 6]. Another large block (S1070) [Fig. 6, Pl. 5] was decorated with a sphin ${ }^{15}$ or more likely a reclining lion, bordered by a large trefoil lotus flower between two lotus buds. ${ }^{16}$ Apart from the construction debris, several small finds were retrieved from the strata, including a fragment of a terracotta libation basin (F19/002), a glass bead (SM19/181), a bone piercing-jewel (SM19/144), and numerous quern stones. Cranial remains of a badly disturbed burial of an infant (FEA 548) were uncovered in the debris near the surface, supplementing the information on an infant cemetery that formed in the area in the late antiquity. ${ }^{17}$

\section{[3] Cemetery WBN C260}

\section{Trench T71}

The purpose of the trench was to ascertain the extension of graves of cemetery WBN $\mathrm{C} 260{ }^{18}$ i.e. within and in the vicinity of kiosk WBN 390. The trench was set and gradually extended in three phases to a final dimension of $15 \times 10 \mathrm{~m}$. Three burials were found, all of them belonged to nonadults. Burials WBN C271 and WBN C272 likely mark the eastern limit of cemetery WBN C260. Their north-west - south-east orientation and the depth of the burial pits were in accordance with the graves excavated in the previous seasons. ${ }^{19}$ Burial WBN C271 was remarkable for the prone position of the body, while the head was rotated facing upwards, and eleven ostrich eggshell beads

14 See Onderka 2012, Fig. 6, Pls. 8-9.

15 See Chapman and Dunham 1952, Pls. 7A-B, 18E.

16 See inter alia Chapman and Dunham 1952, Pls. 8B, 13A; Hintze et al. 1971, Tf. 70; Hintze et al. 1993, Abb. 191; for the combination of lions and lotus flower with buds, see particularly Hintze et al. 1971, Tf. 81,85 .

17 See Onderka 2012, p. 132; Onderka 2016, p. 25.

18 Jungová 2020, Fig. 1.

19 Jungová 2020. 
that originally formed a necklace (SM19/131); burial WBN C272 did not include any burial goods. Burial WBN C273 is most likely a later intrusion, as indicated by its different orientation, absence of a burial pit and shallow position. Burials WBN C271 and WBN C272 were retrieved; burial WBN C273 was left in situ due to high fragility of the remains and because of its irrelevance for the research purposes. Several other depressions that, in their size and shape, would correspond to burial pits, proved to be empty, including a large oval pit with two pairs of cavities sunk laterally at its bedrock bottom.

A large number of circular pits were uncovered in the trench. They form a possible base for a linear structure (wall?) constituted of a large number of wooden poles and at least two perpendicular fence-like structures. The pits were cut into the sāra bedrock that formed the ground of the trench. In this area, the bedrock was crumbly and mixed with pebbles, which in some cases complicated the assessment of exact dimensions and relations between the individual pits. A ring of fired bricks ${ }^{20}$ (FEA 168) formed for protecting a tree was found east of the presumed wall. The ring featured a water inlet composed of a perpendicular flat-laid brick flanked by two bricks standing on the long edge, complemented by a fragment of pottery that served as a funnel inside the tree pit (FEA 169) that was situated below. Similar planters have been uncovered in the Typhonium (WBN 200) ${ }^{21}$ as well as at other sites. ${ }^{22}$

\section{[4] Cemetery WBN C300}

\section{Trench $\mathrm{T70}$}

The trench was originally excavated as a quadrant of tumulus WBN C301, but it was gradually expanded to a square of $5.65 \times 5.65 \mathrm{~m}$ [Fig. 7]. A mudbrick wall, lined with fired bricks on its southern face (FEA 302), was uncovered along the northern side of the trench, crossing it from east to north-west. Its position and orientation suggest it was an external wall of the Isis Temple (WBN 300). The wall has slid to the north in at least two places. Destruction of fired bricks in the central part of the trench coming from the wall included cornices, torus mouldings and a large amount of plaster. Some of the plaster was still in situ, which will require a careful approach when re-opening the trench in the future seasons.

Finds from the core of the tumulus included reused fragments of sandstone reliefs. A piece of Altar B (F19/003) came from the north-eastern part of the trench.

A grave of an adult male WBN C301 was identified (FEAs 309 and 310), cut deep into the brick destruction. The body was interred in an extended supine position with hands placed on the lap. The head was oriented to the south; the feet were nearly touching the wall. The remains were well preserved and displayed no major pathologies. No burial goods were identified, but the body was wrapped in a woven textile. Some fragments remained well-preserved and were sampled and documented.

The bottom level of the trench has not been reached. The excavations were tentatively stopped at the burial level south of the wall FEA 302; the area north of it is yet to be excavated.

20 Jungová 2020, Fig. 1.

21 Onderka et al. 2013, p. 5, Pl. 1; Onderka et al. 2017b, pp. 98-99, Fig. 4, Pl. 4.

22 Macadam 1955, pp. 221-222, Figs. 78, 79; Török 1997, p. 193, Pls. 161, 162; Wolf et al. 2015, p. 123. 


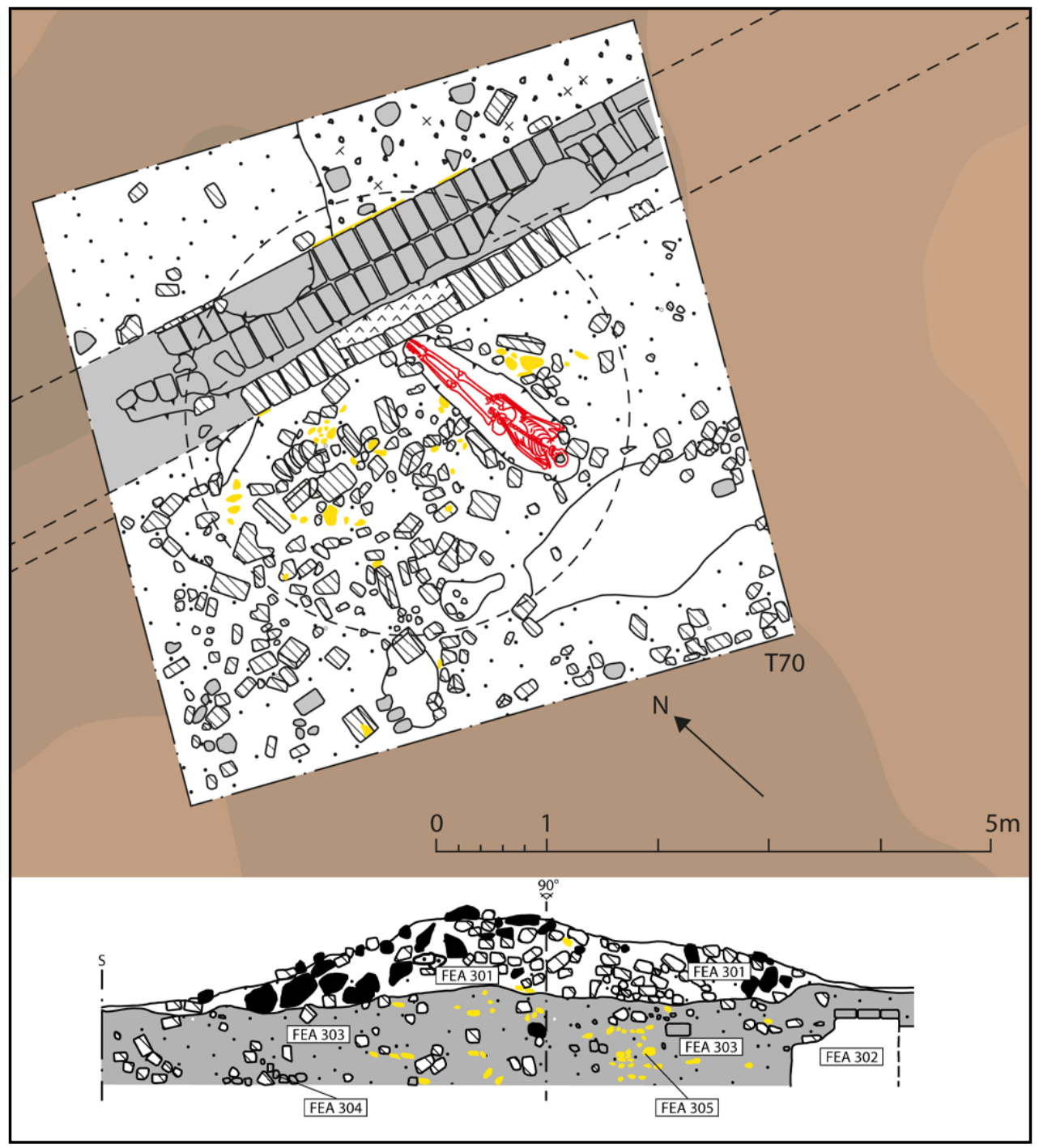

Fig. 7. Top plan at the end of excavations and section of trench T71.

(Illustration: Gabriela Jungová, Vlastimil Vrtal).

\section{Conclusion}

The eighteenth excavation season further contributed to our understanding of the temple precinct located in the western part of Central Wad Ben Naga during its heyday and during the subsequent period of decline. The present state of our knowledge concerning the so-called Isis Temple (WBN 300) enables us to state that its architects and designers sought inspiration in the Isis Temple at Philae, the side entrance inserted to the northern tower of the pylon represents a compelling argument, further supported by the inscription found on the block inserted into the pylon, the text of 
which had its template in the corresponding inscription carved on the First Pylon of the Isis Temple at Philae.

Further excavation in the area of the building WBN 250 has helped to clarify the overall appearance of the structure and especially its development. The complex stratigraphy that was recovered represented at least two distinct phases of construction and subsequent decay. More evidence for monumental construction activities in the area was provided by various sandstone architectural elements recovered.

During the season, the exploration of cemetery WBN C260 was completed. It yielded fourteen individuals in thirteen graves. Twelve burials are relatively dated as post-Meroitic or Christian, one as a slightly later intrusion. Out of the thirteen individuals, four were of adult age, while the rest were sub-adult (mainly toddlers). ${ }^{23}$

The excavation of tumulus WBN C301 built on top of kom $C$ has yielded a simply furnished male burial. The burial pit was dug deep into the debris from destruction, forming the mass of the kom. A fired brick wall was located near the tumulus which likely represented the external wall of the Isis Temple (WBN 300).

\section{Literature:}

Chapman, S. E. and Dunham, D. (1952). Decorated chapels of the Meroitic pyramids at Meroë and Barkal. The Royal Cemeteries of Kush 3. Boston.

Hintze, F. et al. (1971). Musawwarat es Sufra. Band 1, 2: der Löwentempel. Tafelband. Unter Mitwirkung von Ursula Hintze, Karl-Heinz Priese, Kurt Stark. Berlin.

Hintze, F. et al. (1993). Musawwarat es Sufra. Band 1, 1: der Löwentempel. Textband. Berlin.

Jungová, G. (2020). Burials from Cemetery Wad Ben Naga C260 - First Report. Annals of the Náprstek Museum 41/2, pp. 155-167.

Junker, H. (1958). Der große Pylon des Tempels der Isis in Philä. Wien.

Kroeper, K. (2006). Metamorphoses of the Amun Temple in Naga. In: I. Caneva and A. Roccati, eds, Acta Nubica 6. Proceedings of the X International Conference of Nubian Studies. Rome, 9-14 September 2002, Rome, pp. 287-295.

Macadam, M. F. L. (1955). The temples of Kawa II: history and archaeology of the site. Oxford.

Onderka, P. (2012). Preliminary Report on the Third Excavation Season of the Archaeological Expedition to Wad Ben Naga. Annals of the Náprstek Museum 33, pp. 117-134. 
Onderka, P. (2016). Wad Ben Naga report I: An introduction to the site. Prague.

Onderka, P. et al. (2013). Preliminary Report on the Fifth Excavation Season of the Archaeological Expedition to Wad Ben Naga. Annals of the Náprstek Museum 34/2, pp. 3-18.

Onderka, P. and Vrtal, V. (2018). The Typhonium of Wad Ben Naga. M. Honegger, ed., Nubian archaeology in the XXIst century: proceedings of the thirteenth International Conference for Nubian Studies, Neuchâtel, 1st-6th September 2014. Leuven, pp. 415-422.

Onderka, P., Vrtal, V. et al. (2014). Núbie. Země na křižovatce kultur. / Nubia. A Land on the Crossroads of Cultures: Wad Ben Naga 2014. Prague.

Onderka, P. and Vrtal, V. and Gatzsche, A. (2017a). Preliminary Report on the Twelfth Excavation Season of the Archaeological Expedition to Wad Ben Naga. Annals of the Náprstek Museum 38/1, pp. 113-122.

Onderka, P., Vrtal, V. and Gatzsche, A. (2017b). Preliminary Report on the Thirteenth Excavation Season of the Archaeological Expedition to Wad Ben Naga. Annals of the Náprstek Museum 38/2, pp. 93-104.

Onderka, P., Vrtal, V. and Gatzsche, A. (2018). Preliminary Report on the Fourteenth Excavation Season of the Archaeological Expedition to Wad Ben Naga. Annals of the Náprstek Museum 39/1, pp. 95-108.

Onderka, P., Vrtal, V. and Honzl, J. (2019a). Preliminary report on the sixteenth excavation season of the Archaeological Expedition to Wad Ben Naga. Annals of the Náprstek Museum, 40(1), pp. 133-147.

Onderka, P., Vrtal, V. and Jungová, G. (2019b). Preliminary report on the seventeenth excavation season of the Archaeological Expedition to Wad Ben Naga. Annals of the Náprstek Museum, 40(2), pp. 107-120.

Priese, K.-H. (1984). Orte des mittleren Niltals in der Überlieferung bis zum Ende des christlichen Mittelalters. In: F. Hintze, ed., Meroitistische Forschungen 1980: Akten der 4. internationalen Tagung für meroitistische Forschungen vom 24. bis 29. November 1980 in Berlin. Berlin, pp. 484-497.

Török, L. (1997). Meroe City, an ancient African capital: John Garstang's excavations in the Sudan. Egypt Exploration Society, Occasional Publications 12 (1-2). London.

Wolf. P., Nowotnick, U. and Hof, C. (2015). Hamadab - Insights into development and lifestyle of a Meroitic urban settlement. In: M. H. Zach, ed., The Kushite world: proceedings of the 11th international conference for Meroitic studies, Vienna, 1-4 September 2008. Vienna, pp. 123-139. 


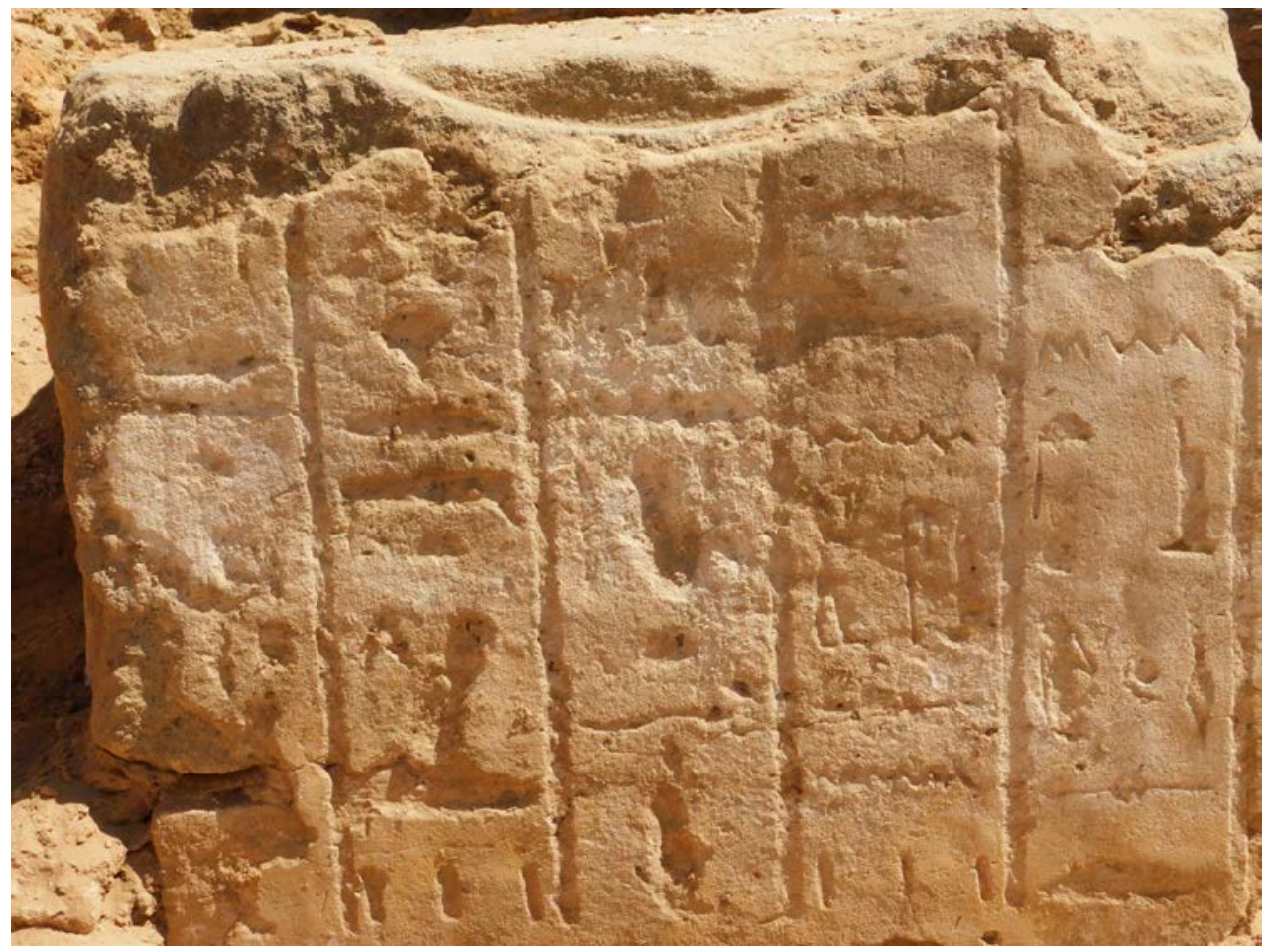

P1. 1. Inscribed sandstone block (FEA $225=$ S966) recovered from trench T64 (Photo: Pavel Onderka).

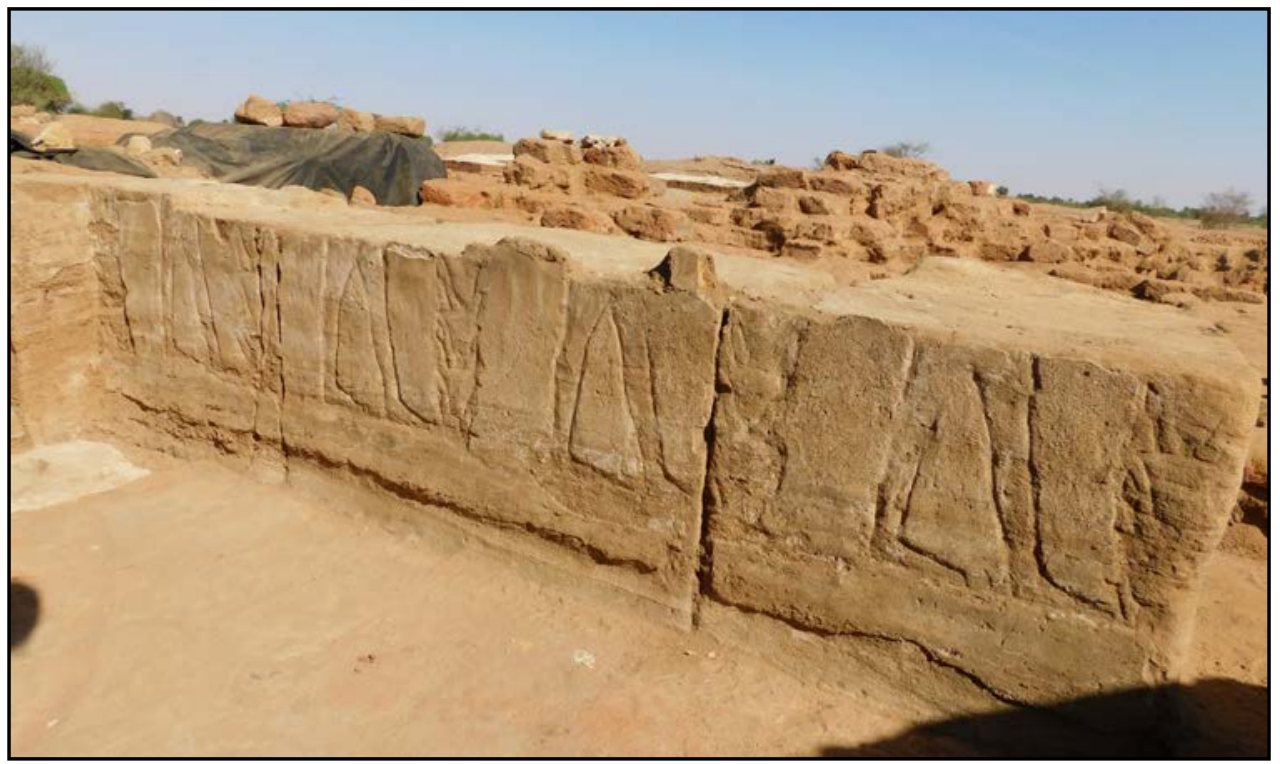

Pl. 2. Preserved part of the lowermost register of the jamb and casing of the doorway in the northern tower of the temple's pylon (Photo: Pavel Onderka). 


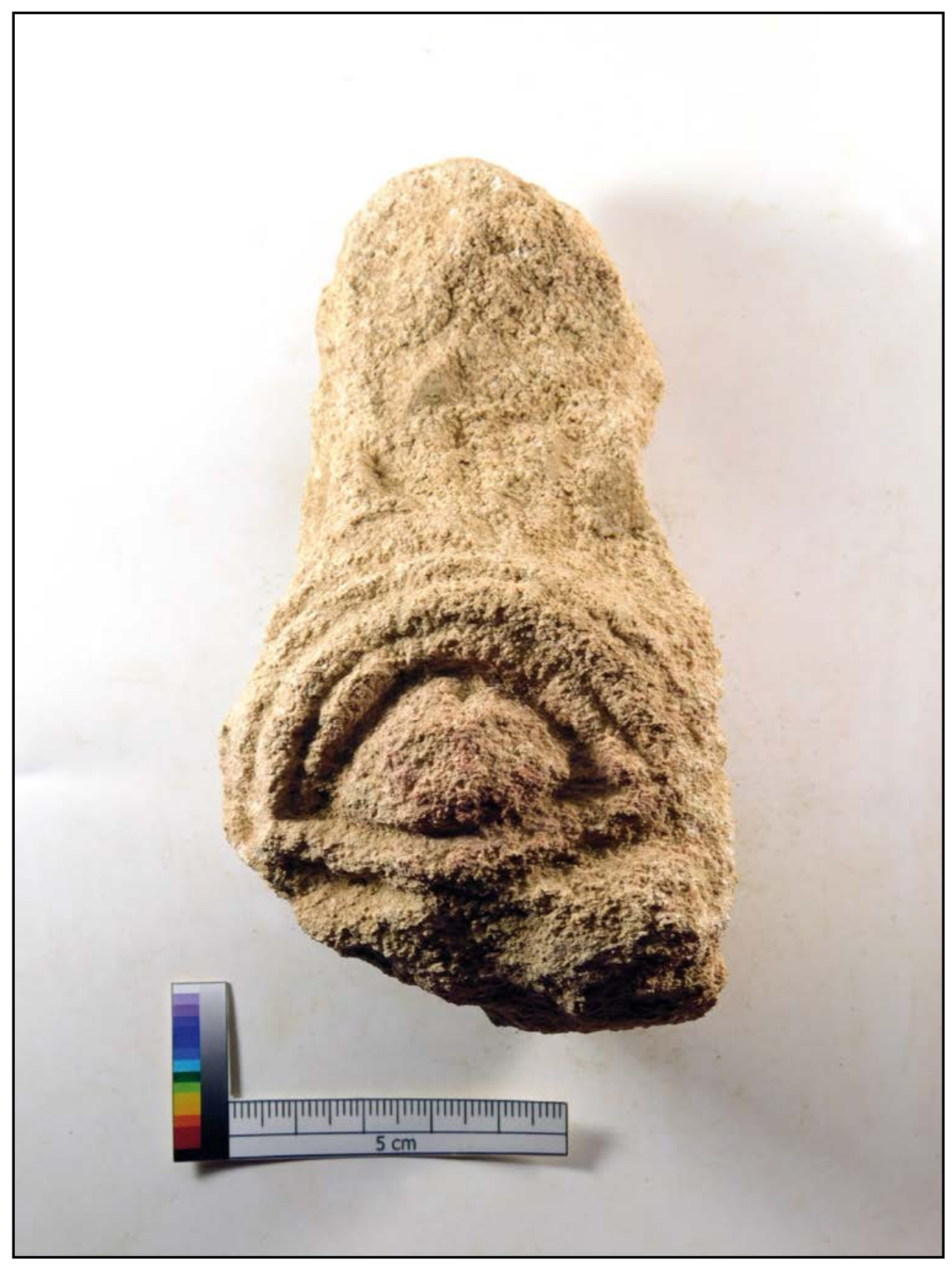

P1. 3. A fragment of a head of Bes (SM19/056) recovered from Trench T64 (Photo: Pavel Onderka). 


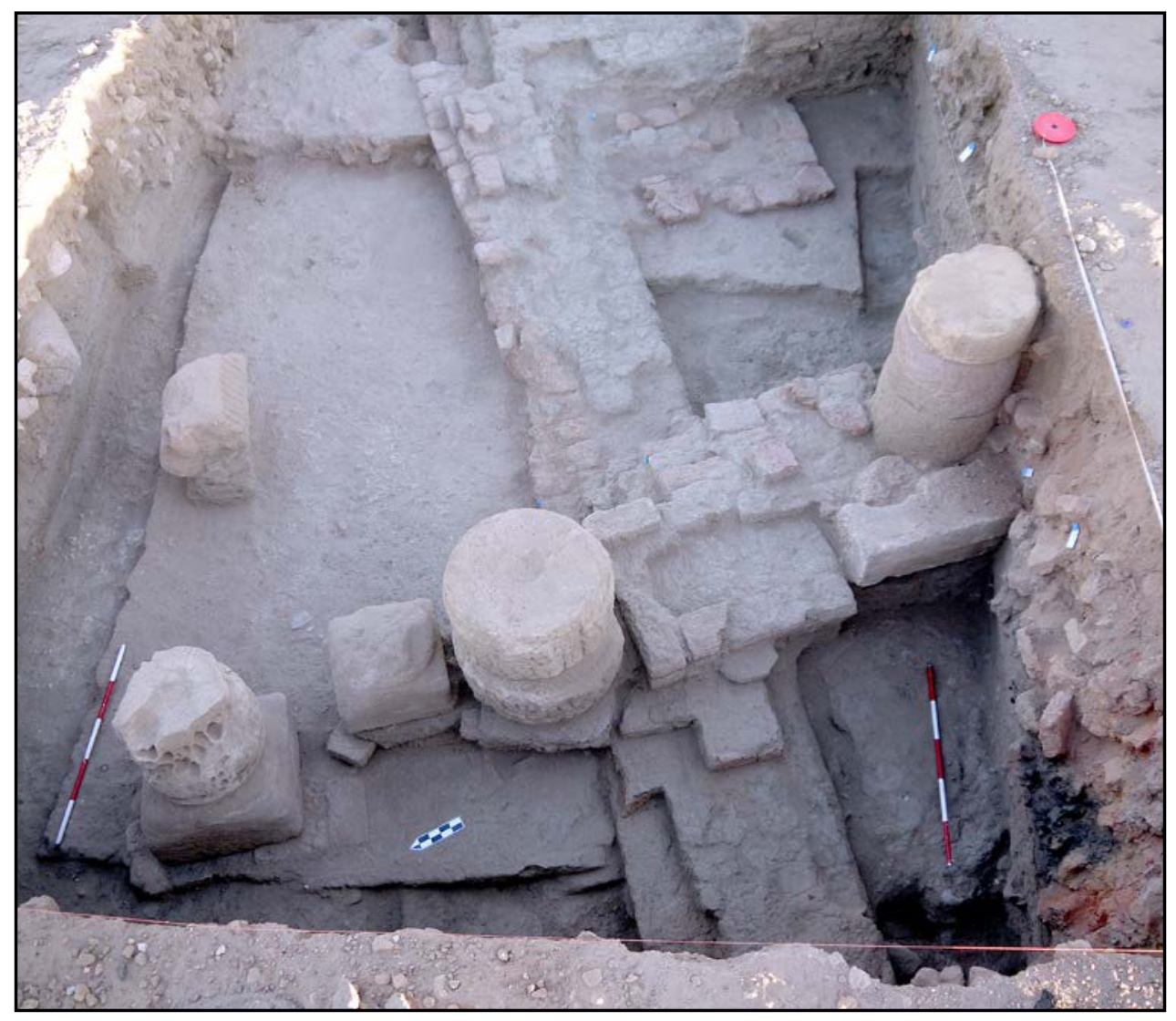

Pl. 4. Western part of trench T69 at the end of excavations

(Photo: Vlastimil Vrtal).

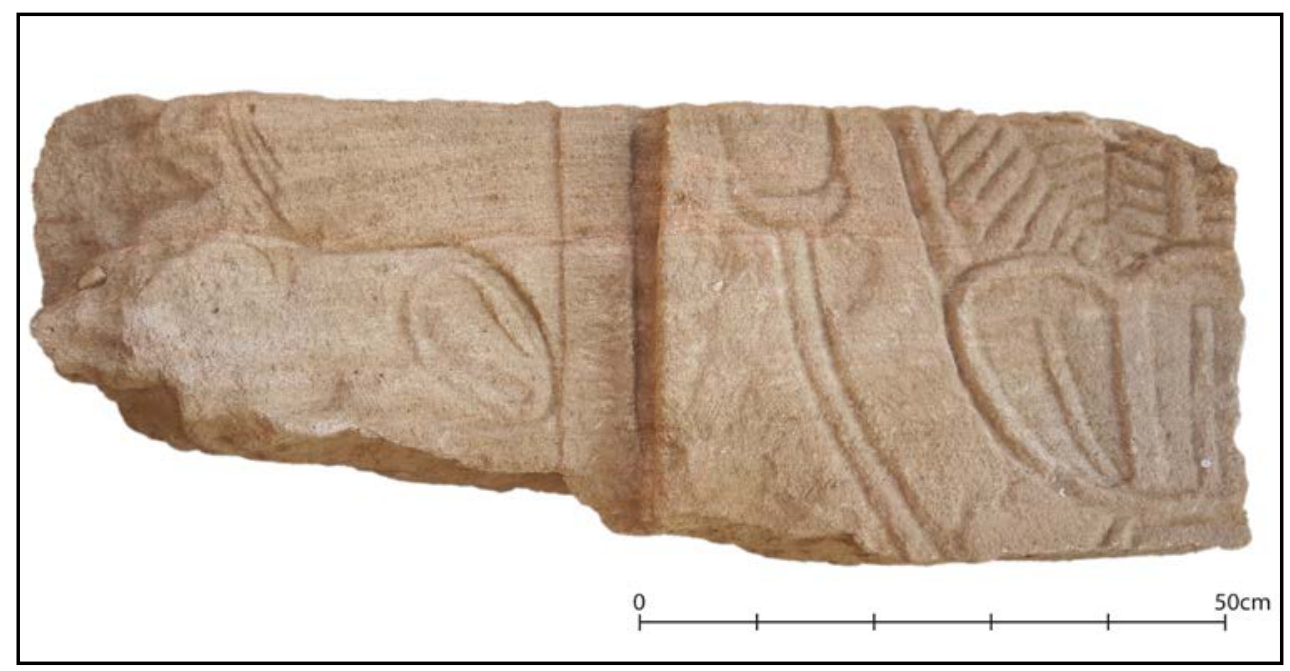

Pl. 5. Block S1070 from trench T69 (Photo: Vlastimil Vrtal). 